\title{
VERTICAL DISTRIBUTION, AGE AND GROWTH RATE \\ OF MURAENOLEPIS MARMORATUS GÜNTHER, 1880 \\ (GADIFORMES, MURAENOLEPIDAE) IN THE AREA \\ OF SOUTH GEORGIA (ANTARCTICA)
}

ROZMIESZCZENIE PIONOWE, WIEK I SZYBKOŚĆ WZROSTU

MURAENOLEPIS MARMORATUS GÜNTHER, 1880

(GADIFORMES, MURAENOLEPIDAE) W REJONIE

GEORGII POLUDNIOWEJ (ANTARKTYKA.)

\section{Department of Biological Marine Resources, Agricultural University of Szczecin, Poland}

The abundance of Muarenolepis marmoratus increases with depth. In December 1987 and January 1988 in bottom trawl catches prevailed 19-23-cm-long specimens, belonging to the age groups V and VI. Growth rate was expressed with use of von Bertalanffy's growth equation with the parameters: $L_{\infty}=48.21 \mathrm{~cm} ; K=0.1188 ; t_{0}=0.1939$ year.

\section{INTRODUCTION}

Abundant literature concerning Antarctic fishes deals mainly with the species which until recently were commercially very important-first of all the families of Nototheniidae and Channichthyidae. Still very little is known about the taxonomy, geographical distribution or life history of the family Muraenolepidae, belonging to the order Gadiformes. The family comprises only one genus, i.e. Muraenolepis, Günther, 1880, with four species: M. marmoratus Günther, 1880,M. microps Lönnberg, 1905, M. orangiensis Vaillant, 1907, and M. microcephalus Norman, 1937. According to many researchers, the status of these species is not very certain, and some revision of this is required (e.g. Tomo and Hureau 1985; Chiu and Markle 1990; Cohen 1990; Howes 1990). Morphometric features, widely recognised as diagnostic for identifying these species, are of little use due to their high variability, what was shown (for the South Georgia region) by Kompowski and Rojas 1993 .

The research on the family Mureanolepidae done so far-apart from some morphological descriptions of the species (inter altere Lönnberg 1905; Norman 1937a, b, 1938; Tomo and Hureau 1985; Gon, 1988; Gon and Klages 1988; Chiu and Markle 1990; 
Cohen 1990; Miller 1993)—concerned: reproduction and fecundity (Permitin 1973), the occurrence and development of eggs and larvae (Efremenko 1983); feeding and food (Permitin and Tarverdeva 1972; Čechun 1984; Kompowski 1993); cranial osteology (Howes 1990) and diagnostic features of Muraenolepis caught off South Georgia (Kompowski and Rojas 1993). Moreover, in different papers there are many references concerning mainly the distribution of larvae from the family in question, or the occurrence of adult specimens in catches or in the food of other species.

The aim of this paper is to provide some additional information about the genus Muraenolepis, which has resulted from the studies of vertical distribution, length, and age composition and growth rate of the species appearing near South Georgia and identifiedbecause of long lateral line reaching far beyond anus-as Muraenolepis marmoratus Günther, 1880.

\section{MATERIAL AND METHODS}

The fish for the present study were caught with a bottom trawl in the shelf waters of South Georgia during the research expedition of RV "Profesor Siedlecki" which took place from 18 December 1987 till 8 January 1988. The places of catches were equally distributed throughout the shelf of the island (see Kompowski 1993).

Total lengths of 1184 individuals (TL) was measured to the nearest $\mathrm{mm}$. The fish were then allocated to $1-\mathrm{cm}$ length classes, the value of length being approximated up or down to the nearest integral number of centimetres. In order to study the vertical distribution of the species, the material caught was divided into three zones, according to the depth of haul: less than $150 \mathrm{~m}, 150$ to $250 \mathrm{~m}$, and more than $250 \mathrm{~m}$. The data as to the depth and time of each haul were taken from the vessel's log-book. The weights of the fish caught in a particular depth zone were reconstructed with use of length frequency distribution and lengthweight relationship.

Out of the catch, 524 individuals were taken at random, and their otoliths, collected for age determination, were stored dry in paper bags. The total weight of each individual was determined to the nearest gram, with use of a rolling-proof scale aboard the ship.

Apart from this, 20 individuals from this trip-as well as further 68 individuals caught in the same way during another trip of RV "Profesor Siedlecki", which took place in the first half of 1989-were brought frozen to Poland. These samples were, among others, used for the determination of the relationship between total length (TL) and standard length ( $S L$ - the distance between the end of snout and the end of hypural plate), as well as for comparative vertebrae-otoliths age readings. The vertebrae, taken both from the anterior and from the posterior parts of spines, were bleached in solution of $\mathrm{H}_{2} \mathrm{O}_{2}$ and stored dry in paper bags. 
The otoliths were measured to the nearest $0.01 \mathrm{~mm}$, according to the scheme given by Hecht (1987), with use of a micrometric screw-equipped microscope. The regression curve, expressing the otolith-total fish length relationship, was adjusted to average fish lengths within each otolith length group every $0.1 \mathrm{~mm}$, and the otoliths length measurements were approximated up or down to the nearest $0.1 \mathrm{~mm}$.

The otoliths and vertebrae were examined for age under a binocular microscope on black background; the otoliths were placed in a few drops of glycerol.

Table 1

The growth rate is

Number of measurements and examinations

\begin{tabular}{|l|c|c|c|}
\hline \multirow{2}{*}{\multicolumn{1}{|c|}{ Type of examination }} & \multicolumn{3}{|c|}{$\begin{array}{c}\text { Number of individuals } \\
\text { examined in season }\end{array}$} \\
\cline { 2 - 4 } & $1987 / 88$ & $1988 / 89$ & Total \\
\hline Measurements of total length & 1184 & 68 & 1252 \\
Measurements of standard length & 20 & 64 & 84 \\
Measurements of weight & 295 & - & 295 \\
Measurements of otolith length & $155+154$ & - & - \\
Age determinations from otoliths & 524 & 57 & 581 \\
Age determination from vertebrae & - & 68 & 68 \\
\hline
\end{tabular}
presented by von Bertalanffy's equation, according to the method described by Beverton and Holt (1957).

The list of the research works carried out is presented in Tab. 1 .

\section{RESULTS}

\section{Vertical distribution and length of Muraenolepis marmoratus} in the area of South Georgia

As from 18 December 1987, until 8 January 1988, RV "Profesor Siedlecki" made 133 bottom trawl hauls in the area of South Georgia. M. marmoratus appeared in almost every haul, though in small quantities. Altogether, 1184 individuals were caught, weighing $148274 \mathrm{~g}$, which made about $0.5 \%$ of the total weight of all species caught.

Table 2

Occurrence of Muraenolepis marmoratus in different depth zones around South Georgia-expressed as a number of individuals and their weight caught per trawling hour

\begin{tabular}{|c|c|c|c|c|}
\hline & \multicolumn{3}{|c|}{ Depth zone in $\mathrm{m}$} & \multirow[t]{2}{*}{ Total } \\
\hline & $<150$ & $\longdiv { 1 5 0 - 2 5 0 }$ & $>250$ & \\
\hline $\begin{array}{l}\text { Fishing effort } \\
\text { (trawling hours } \div \text { minutes) }\end{array}$ & $19 \div 15$ & $37 \div 00$ & $15 \div 50$ & $72 \div 05$ \\
\hline $\begin{array}{l}\text { Number of specimens } \\
\text { caught }\end{array}$ & 66 & 681 & 437 & 1184 \\
\hline Fish weight $(\mathrm{g})$ & 6839 & 98429 & 43006 & 148274 \\
\hline $\begin{array}{l}\text { Number of specimens } \\
\text { caught per trawling hour }\end{array}$ & 3.43 & 18.41 & 27.60 & 16.43 \\
\hline g/trawling hour & 355 & 2660 & 2716 & 2057 \\
\hline
\end{tabular}

M. marmoratus was unevenly distributed, appearing most frequently in the deepest zones, i.e. below $250 \mathrm{~m}$, and the abundance of the species, expressed in weight of fish in grams caught during a one-hour haul, was the highest in the same zone (2716 g) as well as in the zone be- 
tween 150 and $250 \mathrm{~m}$ (2660 g), whereas within the uppermost depth zone, less than $150 \mathrm{~m}$, there was only $335 \mathrm{~g}$ per hour (Tab. 2).

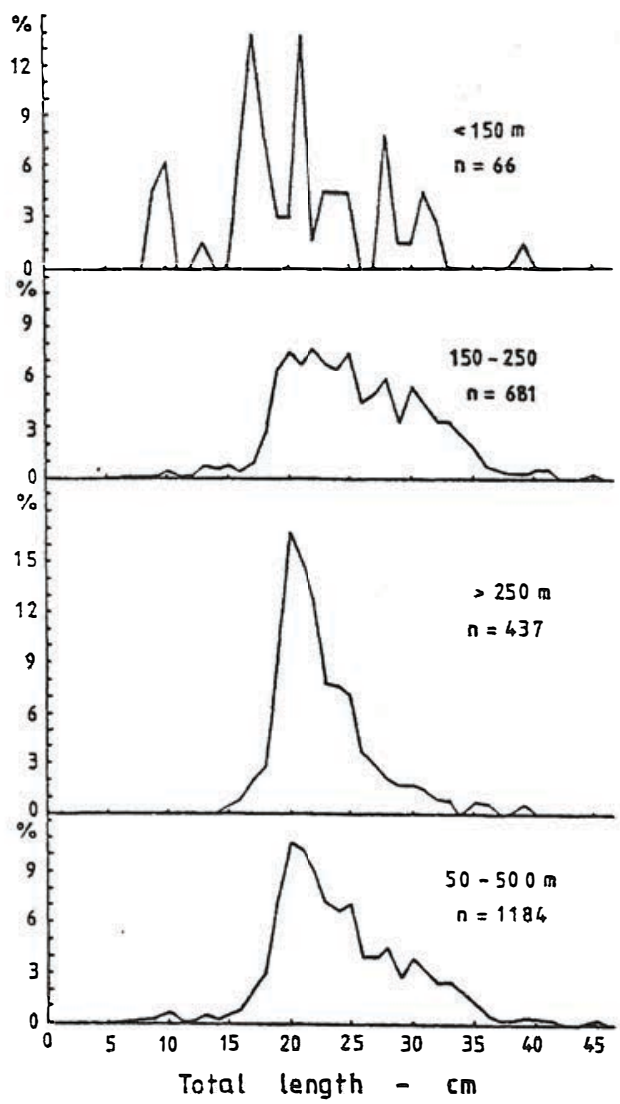

Fig. 1. Length distribution of Muraenolepis marmoratus caught at different depth zones of the South Georgia shelf
The length of the caught fish was between 7 and $45 \mathrm{~cm}$. In the deepest zone, below $250 \mathrm{~m}$, the range was $15-39 \mathrm{~cm}$ with clear prevalence of fish 19-25 cm long, which made altogether $76.5 \%$. The modal length was $20 \mathrm{~cm}$ (Fig. 1).

Between 150 and $250 \mathrm{~m}$ the length range was the widest of all $(7-45 \mathrm{~cm})$, with fish 19-35 cm long prevailing, and no modal length among them could be distinguished (Fig. 1).

Within the uppermost zone (less than $150 \mathrm{~m}$ ) the fish measured from 9 to $39 \mathrm{~cm}$. The length frequency curve showed several maxima

within this range (Fig. 1), though the small number of samples caught does not allow to draw any conclusions from the maxima.

Apparently $2 / 3$ of the fish were immature. Therefore, due to gonad immaturity, accurate sex determination and sexual maturity assessment was not always possible for an unaided eye observation. Within the length class of $24 \mathrm{~cm}$ about half were matured - thus this length can be preliminarily considered as the length of maturation.

Age and growth rate

Otoliths

The otoliths of the studied species are oval or triangular plates, with individual variability in shape. The diversity consists mainly in different development of excisura ostii (terminology according to Hecht 1987) and in various otolith length-width ratio. Differ- 
ences in length between the right and left otolith of the same fish are also quite often noticed. On average though, there is no directed asymmetry of the lengths of the organs, which was confirmed by the studies of the relationship between the lengths of the otoliths and the total lengths of the individuals measuring 88-440 $\mathrm{mm}$ (Fig. 2). This relationship, which according to Hecht (1987), was expressed in a power equation, appeared to be virtually identical for left and right otoliths, amounting respectively:

$$
\begin{gathered}
T L=19.406 \cdot O L^{1.780} ; r=0.985 ; n=155 ; \text { and } \\
T L=19.623 \cdot O L^{1.773} ; r=0.983 ; n=154 ;
\end{gathered}
$$

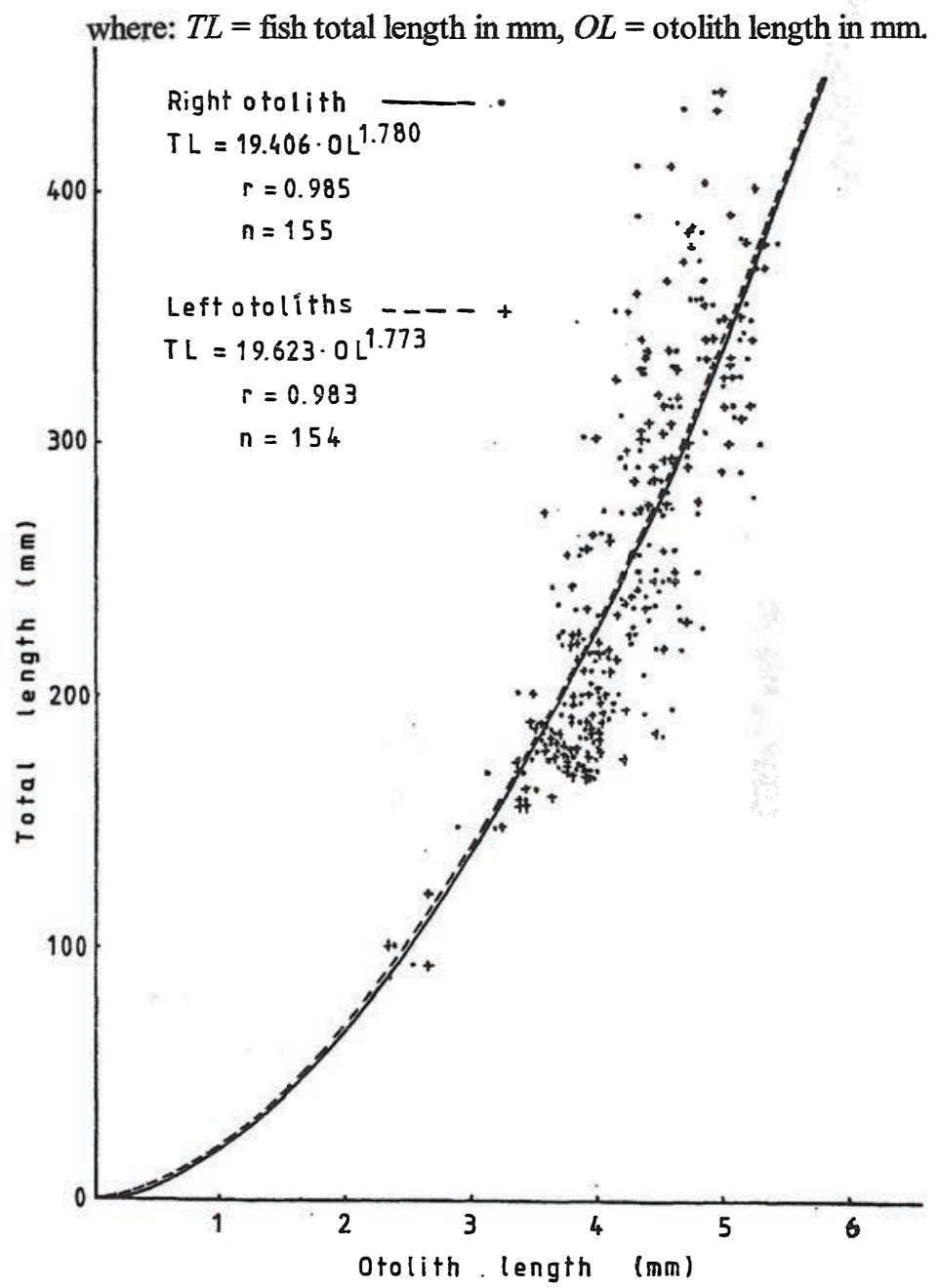

Fig. 2. Relationship between otolith length $(O L)$ and total length (TL) of Muraenolepis marmoratus from the South Georgia region

The external, concave surface of the otoliths was entirely unreadable, whereas on the internal surface, some concentric, alternating opaque and hyaline zones were visible. On the analogy of other fish species, also the Antarctic ones, it has been assumed that a pair of such opaque and hyaline zones (i.e. annulus) represents one year of age (Fig. 3). On the edge of most otoliths hyaline zones were completely formed; some otoliths, especially the ones of young fish, showed additional narrow opaque increments. The otoliths of vast majority, i.e. 515 out of 524 examined individuals, were readable, and their interpretation caused no difficulties. 

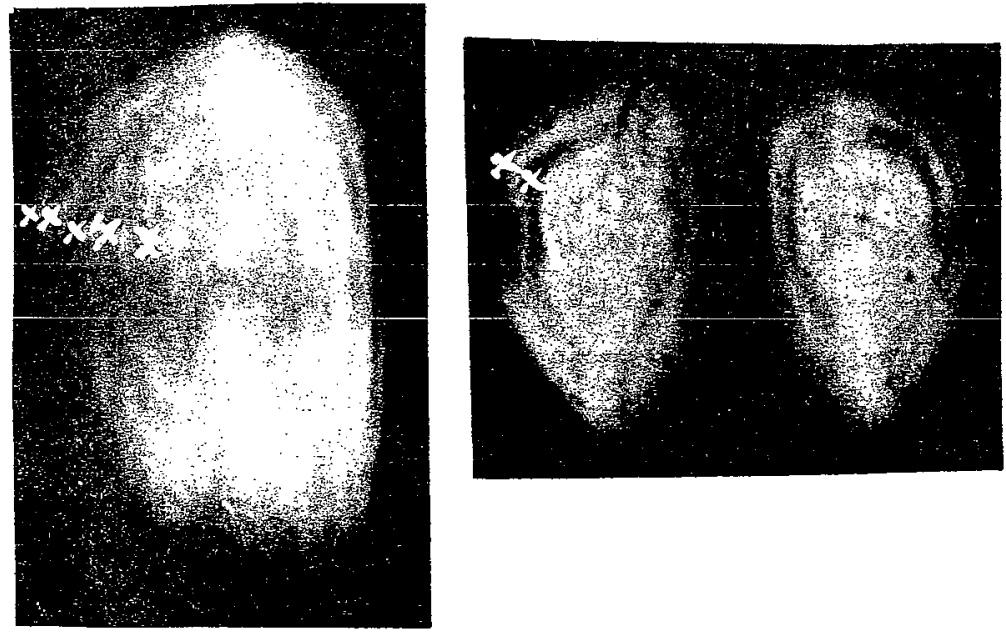

A

B

Fig. 3. Otoliths of Muraenolepis marmoratus caught in the South Georgia shelf waters in the first decade of February 1989; $\mathrm{A}-T L=21.3 \mathrm{~cm}$; age 5 years; $\mathrm{B}-T L=11.0 \mathrm{~cm}$; age 2 years

\section{Vertebrae}

Both anterior and posterior vertebra of $M$. marmoratus has its trunk biconcave, with a quite large aperture. When dipped in water, the oral or caudal surface of the trunk shows

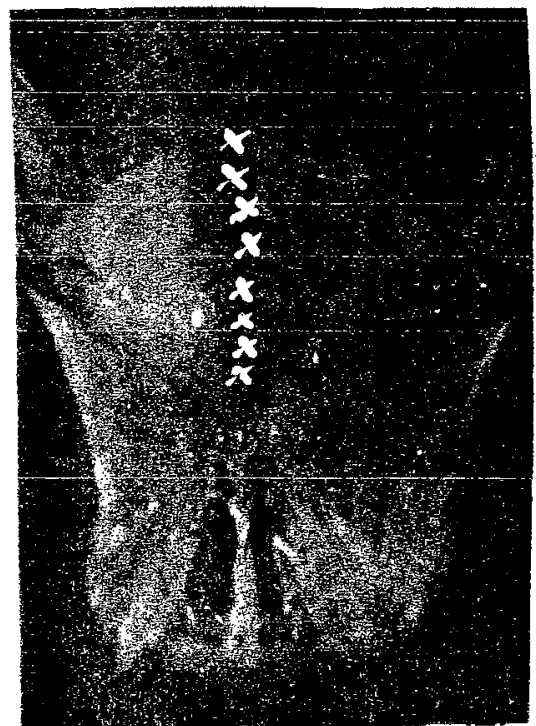

Fig. 4. Cross-section of anterior vertebra of Muraenolepis marmoratus caught in the South Gorgia shelf waters in the first decade of February 1989; $T L=34.0 \mathrm{~cm}$; age 8 years opaque and hyaline zones, which can be seen for a few minutes under a binocular microscope. The number of the zones is generally equal to the number counted on the otolith of the particular individual (Tab. 3). After 3-5 minutes the vertebrae absorbed water and became entirely hyaline and illegible.

In general, the legibility of the vertebrae was much worse and reading was more difficult comparing to the otoliths (Fig. 4), due to circular cracks which appeared because of drying up. 
Table 3

Age readings of Muraenolepis marmoratus from the South Georgia shelf by means of otoliths and vertebrae

\begin{tabular}{|c|c|c|c|c|c|c|c|c|c|}
\hline \multirow{3}{*}{$\begin{array}{l}\text { Seq. } \\
\text { No. }\end{array}$} & \multirow{3}{*}{$\begin{array}{l}\text { Total } \\
\text { length } \\
(\mathrm{cm})\end{array}$} & \multicolumn{3}{|c|}{ Age readings (years) } & \multirow{3}{*}{$\begin{array}{l}\text { Seq. } \\
\text { No. }\end{array}$} & \multirow{3}{*}{$\begin{array}{l}\text { Total } \\
\text { length } \\
\text { (cm) }\end{array}$} & \multicolumn{3}{|c|}{ Age readings (years) } \\
\hline & & \multirow{2}{*}{ Otoliths } & \multicolumn{2}{|c|}{ Vertebrae } & & & \multirow[t]{2}{*}{ Otoliths } & \multicolumn{2}{|c|}{ Vertebrae } \\
\hline & & & Anterior & Posterior & & & & Anterior & Posterior \\
\hline 1 & 14.2 & - & 3 & 3 & 35 & 24.1 & 6 & 6 & 6 \\
\hline 2 & 15.2 & - & 4 & 4 & 36 & 24.6 & 6 & 6 & 6 \\
\hline 3 & 15.5 & - & 4 & 4 & 37 & 24.6 & - & 6 & 6 \\
\hline 4 & 18.6 & 5 & 5 & 5 & 38 & 24.7 & 6 & 6 & 6 \\
\hline 5 & 19.0 & - & 4 & 4 & 39 & 25.3 & 6 & 6 & 6 \\
\hline 6 & 19.0 & 5 & 5 & 5 & 40 & 25.3 & 一 & 6 & 6 \\
\hline 7 & 19.4 & 5 & 5 & 5 & 41 & 25.8 & - & 6 & 6 \\
\hline 8 & 19.7 & 5 & 5 & 5 & 42 & 26.1 & 6 & 6 & 6 \\
\hline 9 & 19.8 & 5 & 5 & 5 & 43 & 26.1 & 7 & 7 & 6 \\
\hline 10 & 20.0 & 5 & 5 & 5 & 44 & 26.3 & 5 & 5 & 5 \\
\hline 11 & 20.3 & 6 & 6 & 6 & 45 & 26.9 & 6 & 6 & 6 \\
\hline 12 & 20.4 & 5 & 5 & 5 & 46 & 27.0 & 10 & 9 & 9 \\
\hline 13 & 20.5 & 5 & 5 & 5 & 47 & 27.0 & 7 & 7 & 7 \\
\hline 14 & 20.5 & 5 & 5 & 5 & 48 & 27.2 & 6 & 6 & 6 \\
\hline 15 & 20.8 & 6 & 5 & 5 & 49 & 27.5 & 7 & 6 & 6 \\
\hline 16 & 20.8 & 5 & 5 & 5 & 50 & 27.7 & 6 & 6 & 6 \\
\hline 17 & 21.0 & 5 & 5 & 5 & 51 & 27.8 & 7 & 6 & 6 \\
\hline 18 & 21.0 & 5 & 6 & 6 & 52 & 28.2 & 7 & 7 & 7 \\
\hline 19 & 21.2 & 5 & 5 & 5 & 53 & 28.2 & 8 & 8 & 8 \\
\hline 20 & 21.2 & 6 & 5 & 5 & 54 & 28.2 & 7 & 7 & 7 \\
\hline 21 & 21.3 & 5 & 5 & 5 & 55 & 28.6 & - & 6 & 6 \\
\hline 22 & 21.3 & - & 5 & 5 & 56 & 29.0 & 7 & 7 & 7 \\
\hline 23 & 21.4 & 5 & 5 & 5 & 57 & 29.0 & 8 & 8 & 8 \\
\hline 24 & 21.5 & 5 & 5 & 5 & 58 & 29.3 & 10 & 10 & 10 \\
\hline 25 & 22.5 & 5 & 5 & 5 & 59 & 29.3 & - & 10 & 9 \\
\hline 26 & 22.5 & 5 & 5 & 5 & 60 & 29.5 & $7 ?$ & 7 & 7 \\
\hline 27 & 22.5 & 6 & 6 & 6 & 61 & 29.8 & 9 & 10 & 10 \\
\hline 28 & 22.6 & 6 & 6 & 6 & 62 & 30.8 & 7 & 7 & 7 \\
\hline 29 & 22.8 & 6 & 6 & 6 & 63 & 32.0 & ? & 10 & 10 \\
\hline 30 & 22.8 & 6 & 6 & 6 & 64 & 34.0 & - & 8 & 7 \\
\hline 31 & 23.1 & 6 & 6 & 6 & 65 & 34.9 & 8 & $8 ?$ & $8 ?$ \\
\hline 32 & 23.5 & 6 & 6 & 6 & 66 & 35.0 & 9 & 8 & 9 \\
\hline 33 & 23.6 & 5 & 6 & 6 & 67 & 37.1 & 13 & 11 & 11 \\
\hline 34 & 23.7 & 8 & 6 & 6 & 68 & 37.6 & 9 & 9 & 9 \\
\hline
\end{tabular}

\section{Age composition of catch}

At the end of December 1987 and in the beginning of January 1988 fish of the age groups II-XII appeared in the catch. The most numerous were the fish belonging to the groups V, 34.9\%, and VI, 27.7\%, (Tab. 4). The fish belonging to the age groups VII-IX made $27.2 \%$ of the catch. What should be noticed, the groups II and III composed a very small part and the group I was completely absent. 
Table 4

Age composition of Muraenolepis marmoratus caught in the South Georgia shelf waters in 1987/88

\begin{tabular}{|c|r|r|r|r|r|r|r|r|r|r|r|r|}
\hline & \multicolumn{10}{|c|}{ Age groups } & Total \\
\cline { 2 - 12 } & II & III & IV & V & VI & VII & VIII & IX & X & XI & XII & \\
\hline$\%$ & 0.4 & 1.0 & 5.4 & 34.9 & 25.7 & 13.5 & 8.2 & 5.5 & 3.3 & 1.1 & 1.0 & 100.0 \\
$\mathrm{n}^{*}$ & 5 & 12 & 63 & 407 & 300 & 158 & 96 & 64 & 39 & 13 & 12 & 1169 \\
\hline
\end{tabular}

* Number of specimens in age groups after converting age readings into weight.

\section{Length growth rate}

Some authors measure the Antarctic fishes according to standard length $(S L)$, the majority however use total length $(T L)$. In order to make the growth rate comparable in terms of both kinds of length, the relationship between $T L$ and $S L$ was determined, with use of the material of 84 individuals of $M$. marmoratus, measuring from 142 to $376 \mathrm{~mm}$ of total length. For this range of length the relation is approximately rectilinear and can be expressed as the following equation:

$$
\begin{gathered}
S L=0.948 \cdot T L+1.116 ; r=0.999 ; \text { or } \\
T L=1.055 \cdot S L-1.177 ;(S L \text { and } T L \text { in } \mathrm{mm}) .
\end{gathered}
$$

The mean lengths of $M$. marmoratus within each age group are shown in Tab. 5 . Because of the small number of fish belonging to the age groups II and III, the mean lengths presented should be treated as provisional. The wide length range of fish in the same age is what should be stressed, especially in the groups VII-IX.

On the base of the average lengths of the age groups from Tab. 5, the following parameters of von Bertalanffy's growth equation were derived: $L_{\infty}=48.21 \mathrm{~cm} ; K=0.1188$; to $=0.1939$. In the same table the theoretical lengths in particular age groups are presented, calculated with use of von Bertalanffy's equation with the above parameters. These theoretical lengths match the empirical data quite well.

\section{Length-weight relationship and weight growth rate}

Length-weight relationship is presented as the power equation:

$$
W=0.00775 \cdot T L^{3.00234} ; r=0.95023 ; n=295 ;
$$

where: $W=$ fish total weight $(\mathrm{g}) ; T L=$ total length $(\mathrm{cm})$. The length range of the fish used for the above was $8.8 \mathrm{~cm}$ to $44.0 \mathrm{~cm}$; the weight between $4.4 \mathrm{~g}$ and $780.0 \mathrm{~g}$.

Substituting TLs with the theoretical lengths in the particular age groups, the theoretical weights were calculated for the individuals of the studied species in the subsequent years of life (Tab. 5). 
Table 5

Mean length in the age groups of Muraenolepis marmoratus in the South Georgia shelf waters in 1987/8.8

$(\mathrm{TL}-\mathrm{cm})$ and theoretical length and weight according to the von Bertalanffy's formula

\begin{tabular}{|c|c|c|c|c|c|c|c|c|c|c|c|}
\hline \multirow[t]{2}{*}{ Parameter } & \multicolumn{11}{|c|}{ Age groups } \\
\hline & II & III & IV & $\mathrm{V}$ & VI & VII & VIII & IX & $\mathrm{X}$ & $\mathrm{XI}$ & XII \\
\hline Mean length of age groups [cm] & 9.4 & 12.7 & 18.2 & 20.6 & 23.8 & 27.1 & 29.7 & 31.5 & 32.7 & 34.8 & 36.3 \\
\hline$\pm \sigma$ & - & 3.7 & 2.0 & 1.7 & 2.3 & 3.0 & 3.1 & 3.4 & 2.9 & 3.4 & 3.7 \\
\hline Range & $9-11$ & $10-19$ & $15-22$ & $16-25$ & $19-31$ & $21-34$ & $23-39$ & $25-39$ & $27-38$ & $31-44$ & $33-41$ \\
\hline Number of age readings & 3 & 4 & 28 & 169 & 122 & 75 & 50 & 32 & 19 & 8 & 5 \\
\hline Theoretical length [cm] & 9.3 & 13.7 & 17.6 & 21.0 & 24.1 & 26.8 & 29.2 & 31.3 & 33.2 & 34.9 & 36.4 \\
\hline Theoretical weight [g] & 9.3 & 20.0 & 42.2 & 72.3 & 108.6 & 149.7 & 193.9 & 239.6 & 285.9 & 331.6 & 376.3 \\
\hline
\end{tabular}




\section{DISCUSSION}

Any comparisons of our results with the observations of other authors is difficult due to the uncertain status of the species belonging to the family Muraenolepidae. Earlier sources (e.g. Norman 1938; Andriashev, 1965; Permitin 1977; Howes 1990) state that in the area of South Georgia there is only one species, i.e. M. microps. Tomo and Hureau (1985), are the first authors to state that there exists also M. microcephalus in the area. Balguerias (1989), in the report from a research trip during 1986/87, mentions two $\mathrm{Mu}$ raenolepis species being caught off the island, $M$. microps and $M$. orangiensis. Cohen (1990), reports about two other species, M. microps and M. microcephalus. Chiu and Markle (1990), on the contrary, state that as much as three species live in waters around the island: M. microps, M. marmoratus and M. microcephalus; the same is reported by Miller (1993). What can be clearly seen, all the authors agree as to the presence of M. microps. None of the cited authors though, who report seeing more than one Muraenolepis species in the area, provide any results of feature studies that might justify such opinion. Moreover, none of them is critical to earlier opinions about geographical distribution of Muraenolepis. According to the cited sources, one might presume that all four species of the family, recognised so far, coexist in the area of South Georgia. Our studies though (Kompowski and Rojas 1993) lead to the conclusion that there lives only one species-identical to that previously recognised as M. microps. Long lateral line suggests that it is M. marmoratus. Should we suppose that our hypothesis is true, and all the previous reports and references pertain to one and the same species, we can than draw comparisons.

The abundance of $M$. marmoratus was increasing with depth during the research period of Antarctic summer 1997-1988. It is compliant with the observations made by Balguerias (1989), in the same area during the Antarctic summer 1986-1987. His observations concern two species distinguished by him: M. microps and M. orangiensis.

The relationship between fish total length and otolith length estimated in this work differs from that given by Hecht (1987), who reports the relationship for M. microps from the South Georgia area (for both left and right otoliths together) as follows: $T L=28.21 \cdot O L^{1.60}$. It is also a power type relationship, however, the differences can arise from much smaller volume of material studied by Hecht (otoliths measurements from 47 individuals of total length $157-390 \mathrm{~mm}$ ).

No studies of age or growth rate of Muraenolepidae have been carried out so farexcept for Permitin's (1973), who-studying fecundity and reproductive biology of various species of the area-estimated also age of some individuals of M. microps, using otoliths but giving no details of that. He reports only that males of this species mature at the length of 21-27 cm, at the age of 3-5 years, and that females at $16-19 \mathrm{~cm}$, with three annuli on the otoliths, were still immature. However, larger females, more than $30 \mathrm{~cm}$ long and more than 
4 years old, had their gonads well developed. At this point it is worth to mention that Permitin's observations on gonad development and maturation converge with our initial observations.

North (1988 a), ascertained that hyaline otolith zones of the Antarctic fishes start to deposit in July and August and are clearly visible on the edge of most otoliths from August till September. This meet our observations, as the otolith of all the fish examined-caught during Antarctic summer (December-January) - had a hyaline zone fully formed on the edge, and smaller individuals had also some narrow opaque increments.

The reason for the age-group I absence and a small part of the groups $I$ and $I I I$ in the catch is that the larvae and postlarvae of Muraenolepidae (the groups 0 and I) remain in the pelagial (Efremenko 1983; North 1988 b) thus were unavailable for the bottom trawl used by RV "Profesor Siedlecki". The selectivity of the trawl is an explanation for the small catch of the groups II and III. The smallest individuals caught were $88 \mathrm{~mm}$ and $93 \mathrm{~mm}$ of total length. There were two distinct hyaline zones on their otoliths, so they were estimated to be within the group II. Bearing in mind that spawning of Muraenolepis probably fall at the end of Antarctic winter (Permitin 1973; Efremenko 1983), it should be accepted that the actual age of the fish was approximately 2.5 years, 3.5 years and so forth.

According to Taylor (1958), $L_{\infty}$ should be fitted in such a way that $L_{\max }$ (maximum length observed for the species) amounts to about $95 \%$ of the $L_{\infty}$ (see also Ekau 1988). Maximum reported length of Muraenolepis (M. microps) was $46 \mathrm{~cm}$ in the area of South Georgia (Permitin 1973), only $1 \mathrm{~cm}$ more than the largest individual of our studies. Our $L_{\infty}=48.21 \mathrm{~cm}$ conforms Taylor's criterion, as $L_{\max }=46 \mathrm{~cm}$ is $95.42 \%$ of the $L_{\infty}$.

\section{CONCLUSIONS}

1. The maximum abundance of Muraenolepis marmoratus in the region of South Georgia in australian summer 1987/88 was observed at depths $>250 \mathrm{~m}: 2716 \mathrm{~g}$ per trawling hour-as compared with $335 \mathrm{~g}$ per wawling hour at the depth zone $<150 \mathrm{~m}$.

2. In bottom trawl catches occurred 7-45 m long specimens; 19-23 cm long specimens prevailed.

3. The relationship between otolith length $(O L, \mathrm{~mm})$ and total length $(T L, \mathrm{~mm})$ of $M u$ raenolepis marmoratus were for right and left otoliths respectively: $T L=19.406 \cdot O L^{1.780}$; $r=0.985 ; n=159$ and $T L=19.623 \cdot O L^{1.773} ; r=0.983 ; n=154$.

4. The otoliths were better for age readings than the vertebrae and their interpretation was relatively easy.

5. Specimens of II-XII age groups occurred in the catches; V and VI age groups were most abundant. 
6. Growth rate was expressed with the von Bertalanffy's growth equation with the parameters: $L_{\infty}=48.21 \mathrm{~cm} ; K=0.1188 ; t_{0}=0.1939$ year.

\section{ACKNOWLEDGMENT}

The authors wish to thank all who contributed in the success of this work, especially Jacek Szlakowski MSc, for providing us with frozen material collected by himself during the research expedition on board of RV "Profesor Siedlecki".

\section{REFERENCES}

Andriashev A.P., 1965: A general review of the Antarctic fish fauna. In: Biogeography and ecology of Antarctica [Van Mieghem J., Van Oye J. (eds.)]. Junk Publ., The Hague: 491-550.

Balguerias E., 1989: Informe de resultados „Antartida 8611”. Publ. Espec. Inst. Espan. Oceanogr., $\mathrm{N} 2: 267-483$.

Beverton R.J., S.J. Holt, 1957: On the dynamics of exploited fish populations. Fishery investigations, ser. II, 19: 1-533.

Chiu T.S., D.F. Markle, 1990: Muraenolepidae. Eel cods. In: Fishes of the Southern Ocean [Gon O., Heemstra P.C. (eds.)]. J.L.B. Smith Inst. Ichthyol.: 179-182.

Cohen D.M., 1990: Family Muraenolepidae. In: Cohen D.M., Inada T., Iwamoto T., Scialabba N.: Gadiform species of the world. FAO Species Catalogue, Rome, 10,: 380-384.

Čechun I.S., 1984: Pitanije i piščevyje vzaimootnošenija nekotorych ryb subantarktičeskich vod Indijskogo Okeana [Feeding and food interrelationship of some subantarctic fishes of the Indian Ocean]. Tr. Zool. In-ta AN SSSR, 127: 38-68. (In Russian).

Efremenko V.N., 1983: Opisanije ilrinok i ličinok Muraenolepis microps Lönnberg (Muraenolepidae) iz moria Skotia [Description of eggs and larvae of Muraenolepis microps Lönnberg (Muraenolepidae) from the Scotia Sea]. Vopr. Ichtiol., 23, 1: 149-152. (In Russian).

Ekau W., 1988: Ökomorphologie nototheniider Fische aus demWedellmeer, Antarktis.Ber. Polarforsch., 51:1-140.

Gon O., 1988: The fishes collected during the South African SIBEX I + II expeditions to the Indian Ocean sector of the Southern Ocean $\left(60-66^{\circ} \mathrm{S}, 48-64^{\circ} \mathrm{E}\right)$. S. Afric. J. Antarct. Res., 18, 2: 55 70.

Gon O., N.T.W. Klages, 1988: The marine fish fauna of the sub-Antarctic Prince Edward Islands. S. Afric. J. Antarct. Res., 18, 2: 32-54.

Hecht T., 1987: A guide to the otoliths of Southern Ocean Fishes. S. Afric. J. Antarct. Res., 17, 1: $1-87$.

Howes G.J., 1990: The syncranial osteology of the southern eel-cod family Muraenolepidae with comments on its phylogenetic relationship and on the biogeography of subantarctic gadoid fishes. Zool. J. Linnean Soc., 100, 1: 73-100.

Kompowski A., 1993: Food and feeding behaviour of eel-cod Muarenolepis sp. (Pisces, Gadiformes, Muraenolepidae) from the region of South Georgia. Acta Ichth. Piscat., 23, 1: 59-68.

Kompowski A., C. Rojas, 1993: On some diagnostic features of Muarenolepis sp. (eel-cod) from the South Georgia shelf. Acta Ichth. Piscat., 23, 1: 89-98. 
Lönnberg E., 1905: The fishes of the Swedish South Polar Expedition. Wiss. Ergebn. Schwed. Südpolarexped. 1901-1903, B. 5 (Zoology), H. 6, 1: 1-69.

Miller R.G., 1993: History and atlas of the fishes of the Antarctic Ocean. Forests Inst. Oc. And Mount. Stud. Spec. Publ., Carson City, Nevada: 1-792.

Norman J.R., 1937a: Coast fishes. Part II. The Patagonian region. Discovery Repts., 16: 1-150.

Norman J.R., 1937b: Fishes. Rep. B.A.N.Z. Antarct. Res. Exped., ser. B, 1, 2: 49-88.

Norman J.R., 1938: Coast fishes. Part III. The Antarctic zone. Discovery Repts., 18: 1-105.

North A.W., 1988a: Age of antarctic fish: validation of the timing of annuli formation in otoliths and scales. Cybium, 12, 2: 107-114.

North A.W., 1988b: Distribution of fish larvae at South Georgia: horizontal, vertical, and temporal distribution and early life history relevant to monitoring year-class strength and recruitment. SC-CAMLR Sel. Sci. Pap/4, Hobart, Australia: 105-141.

Permitim J.E., 1973: Plodovitost' i biologia razmnoženija belokrovnych ryb (sem. Chaenichthyidae), ugretreskovych (sem. Muraenolepidae) i antarktičceskich ploskonosov (sem. Bathydraconidae) morja Skoša (Antarktika) [Fecundity and reproduction biology in white-blooded fishes (fam. Chaenichthyidae), and fishes of family Muraenolepidae and Bathydraconidae of the Scotia Sea (Antarctic]. Vopr. Ichtiol., 13, 2: 245-258. (In Russian).

Permitin J.E., 1977: Vidovoj sostav i zoogeografičeskij analiz fauny donnych ryb morja Skoša [Species composition and zoogeographical analysis of bottom fish fauna of the Scotia Sea]. Vopr. Ichtiol., 17, 5: 843-861. (In Russian).

Permitin J.E., M.I. Tarverdeva, 1972: Pitanije nekotorych vidov antarktičeskich ryb v rajone ostrova Južnaja Georgia [The feeding of some species of Antarctic fishes in the South Georgia area]. Vopr. Ichtiol., 12, 1: 120-132. (In Russian).

Taylor C.C., 1958: Cod growth and temperature. ICES J. Cons., 23, 3: 143-169.

Tomo A., J.-C. Hurean, 1985: Muraenolepidae. In: FAO species identification sheets for fishery purposes. Southern Ocean [Fischer W., Hureau J.-C. (eds.)], Rome, 2: 306-315.

Andrzej KOMPOWSKI, Carlos ROJAS

ROZMIESZCZENIE PIONOWE, WIEK I SZYBKOŚĆ WZROSTU MURAENOLEPIS
MARMORATUS GÜNTER, 1880 (GADIFORMES, MURAENOLEPIDAE)
W REJONIE GEORGII POŁUDNIOWEJ (ANTARKTYKA)

STRESZCZENIE

Latem antarktycznym 1987/88 najobfitsze występowanie Muraenolepis marmoratus w rejonie Georgii Południowej zaobserwowano na głębokościach >250 m: 2716 g/godz. zaciagu - w porównaniu z $335 \mathrm{~g} /$ godz. zaciagu w strefie $<150 \mathrm{~m}$ (Tab. 2). W połowach włokiem dennym wystepowały osobniki o długości całkowitej 7-45 cm. Najliczniejsze były ryby o długości 19-23 cm (Fig. 1).

Zależność między długością otolitu $(O L-\mathrm{mm})$ i długością całkowitą Muraenolepis marmoratus $(T L-\mathrm{mm})$ wynosiła odpowiednio dla prawego i lewego otolitu (Fig. 2$): T L=19.406 \cdot O L^{1.780}$; $r=0.985 ; n=159$ oraz $T L=19.623 \cdot O L^{1.773} ; r=0.983 ; n=154$.

Do odczytów wieku lepiej nadają się otolity niż kręgi (Fig. 3 i 4, Tab. 3). Odczyty wieku $z$ otolitów są łatwe, a ich interpretacja nie przedstawia większych problemów. W połowach włokiem dennych występowały osobniki z II-XII grup wieku; najliczniejsze były ryby z V i VI grupy wieku (Tab. 4). 
Średnie długości osobników w grupach wieku (Tab. 5) obrazują szybkość wzrostu Muraenolepis marmoratus w rejonie Georgii Południowej. Szybkość tę można również przedstawić przy pomocy równania von Bertalanffy'ego z następującymi parametrami: $L_{\infty}=48,21 \mathrm{~cm} ; K=0,1188$, $t_{0}=0,1939$ roku.

Zależność mieddzy długością całkowitą $(T L-\mathrm{cm})$ i masą $(W-\mathrm{g})$ można wyrazić wzorem $W=0,00775 \cdot T L^{3,00234}$.

Received: 2 September 1996

Authors' address:

Andrzej Kompowski PhD DSc ProfTit

Department of Biological Marine Resources

Agricultural University of Szczecin

Kazimierza Królewicza 4, 71-550 Szczecin, Poland 